\title{
Ureibacillus gen. nov., a new genus to accommodate Bacillus thermosphaericus (Andersson et al. 1995), emendation of Ureibacillus thermosphaericus and description of Ureibacillus terrenus sp. nov.
}

\author{
M. Grazia Fortina, ${ }^{1}$ Rüdiger Pukall, ${ }^{2}$ Peter Schumann, ${ }^{2}$ Diego Mora, ${ }^{1}$ \\ Carlo Parini, ${ }^{1}$ P. Luigi Manachini ${ }^{1}$ and Erko Stackebrandt ${ }^{2}$
}

Author for correspondence: M. Grazia Fortina. Tel: +392 23955830. Fax: +392 70630829. e-mail: grazia.fortina@unimi.it

\footnotetext{
1 Department of Food Science and MicrobiologyIndustrial Microbiology Section, University of Milan, 20133 Milan, Italy

2 Deutsche Sammlung von Mikroorganismen und Zellkulturen $\mathrm{GmbH}, 38124$ Braunschweig, Germany
}

\begin{abstract}
A polyphasic taxonomic study was performed on the type strain of Bacillus thermosphaericus DSM $10633^{\top}$ and three related soil isolates. On the basis of phenotypic characteristics, chemotaxonomic profiles and phylogenetic data a new genus, Ureibacillus gen. nov., is proposed for the strains in the Bacillus thermosphaericus cluster. Strains of this cluster fall into two DNA-DNA similarity groups: while one group contains the type strain of Ureibacillus thermosphaericus comb. nov. and a single soil isolate, the other contains two soil isolates. The two groups differed in the composition of isoprenoid quinones and some phenotypic properties. These data support the description of a novel species of Ureibacillus for which the name Ureibacillus terrenus is proposed. The type strain of this new species is TH9A $^{\top}$ ( = DSM $12654^{\top}=$ LMG $^{\circ}$ 19470').
\end{abstract}

Keywords: Ureibacillus gen. nov., Ureibacillus terrenus sp. nov., Ureibacillus thermosphaericus

\section{INTRODUCTION}

Recent taxonomic studies on thermophilic bacilli have shown that this biotechnologically important group of bacteria is still in need of further study to improve its classification and identification. Indeed, in recent years there has been a proliferation of new species described (Manachini et al., 1985; Demharter \& Hensel, 1989; Combet-Blanc et al., 1995; Meier-Stauffer et al., 1996; Pettersson et al., 1996) and, through more detailed phylogenetic and chemosystematic studies, the proposal of new genera (Wisotzkey et al., 1992; Shida et al., 1996; Heyndrickx et al., 1998, Wainø et al., 1999). In this framework Bacillus thermosphaericus represents a thermophilic Bacillus species which is not closely related to members of any of the newly described genera that accommodate former Bacillus species. This species was isolated in 1995 from urban air in Southern Finland (Andersson et al., 1995), but its habitat is as yet unknown as no additional strains of this species

The GenBank accession number for the 165 rDNA sequence of Ureibacillus terrenus is AJ276403. have been isolated. Among the thermophilic bacilli Bacillus thermosphaericus is rather unique as it stands phylogenetically isolated and possesses unique physiological properties. These features have already been stressed in the original description of the species (Andersson et al., 1995) and the new taxon was tentatively assigned to the genus Bacillus.

As part of a study investigating genotypic diversity among thermophilic bacilli (Mora et al., 1998), three strains were isolated from uncultivated soil in three different geographical areas. These strains showed morphological and phenotypic features typical of Bacillus thermosphaericus. Phylogenetic and chemotaxonomic data supported the affiliation but indicated that two of the soil isolates formed a novel species, the description of which is presented in this communication.

\section{METHODS}

Bacterial strains, growth conditions and phenotypic tests. The strains used in this study, designated TH9A ${ }^{\mathrm{T}}, \mathrm{TH} 29 \mathrm{~A}$ and TU1A, had been previously isolated from soil samples 
from Italy, Egypt and Turkey, respectively (Mora et al., 1998). Bacillus thermosphaericus DSM $10633^{\mathrm{T}}$ was used as reference strain. Strains were routinely maintained at $4{ }^{\circ} \mathrm{C}$ after growth at $55^{\circ} \mathrm{C}$ on CESP agar (casitone, $15 \mathrm{~g}$; yeast extract, $5 \mathrm{~g}$; soytone, $3 \mathrm{~g}$; peptone, $2 \mathrm{~g}$; $\mathrm{MgSO}_{4}, 0.015 \mathrm{~g}$; $\mathrm{FeCl}_{3}, 0.007 \mathrm{~g} ; \mathrm{MnCl}_{2}, 0.002 \mathrm{~g}$; made up to 11 with distilled water, $\mathrm{pH} 7 \cdot 2$ ). For long-term maintenance, cell suspensions were stored at $-80{ }^{\circ} \mathrm{C}$ in broth cultures supplemented with $15 \%(\mathrm{w} / \mathrm{v})$ glycerol.

The morphological life-cycle was photographed in a phasecontrast microscope by using cells grown on slides coated with a thin layer of CESP agar. Gram staining was done as described by Salle (1961). Colony characteristics were determined from 24-36-h-old cultures grown at $55^{\circ} \mathrm{C}$. Anaerobic growth in glucose broth, anaerobic production of gas from nitrate, citrate utilization, starch and casein hydrolysis, indole, acetoin and catalase production were determined by the method described by Smith et al. (1952). Reduction of nitrate was examined using the method of Lanyi (1987); the urease test followed the method described by Atlas (1993). Utilization of different carbon sources was tested on agar plates containing $\left(\mathrm{g} \mathrm{l}^{-1}\right)\left(\mathrm{NH}_{4}\right)_{2} \mathrm{HPO}_{4}(1), \mathrm{KCl}$ $(0 \cdot 2), \mathrm{MgSO}_{4}(0 \cdot 2)$, yeast extract $(0 \cdot 2)$, bromocresol purple $(0.004)(\mathrm{pH} \mathrm{7.0)}$ supplemented with $0.5 \%(\mathrm{w} / \mathrm{v})$ of each carbon source sterilized separately. The temperature range for growth was determined on CESP agar plates incubated at different temperatures over the range $35-70{ }^{\circ} \mathrm{C}$. For $\mathrm{pH}$ studies, the $\mathrm{pH}$ of the medium was adjusted from $5 \cdot 0$ to $11 \cdot 0$. Tolerance to salinity was determined in CESP broth supplemented with $2-7 \%(\mathrm{w} / \mathrm{v}) \mathrm{NaCl}$.

Chemotaxonomy. Peptidoglycan structure was elucidated by analyses of cell-wall hydrolysates employing the following methods: qualitative analysis of amino acids and peptides by two-dimensional TLC on cellulose plates using described solvent systems (Schleifer \& Kandler, 1972), quantitative amino acid analysis by GC and GC/MS (MacKenzie, 1987; Groth et al., 1996), dinitrophenylation of N-terminal amino acids of the interpeptide bridge (Schleifer, 1985) and enantiomeric amino acid analysis using a chiral gas chromatographic column (Groth et al., 1997). Menaquinones were analysed by HPLC as described previously (Groth et al., 1996). GC determination of cellular fatty acid profiles was performed as described by Schumann et al. (1997). Polar lipids extracted by the method of Minnikin et al. (1979) were identified by two-dimensional TLC on silica gel and spraying with specific reagents (Collins \& Jones, 1980).

Determination of $\mathbf{G}+\mathbf{C}$ content of DNA. DNA base composition was determined by the thermal denaturation method described by Marmur \& Doty (1962), using the equation of Owen \& Hill (1979). DNA from Escherichia coli strain B (Sigma) was used as internal standard.

DNA-DNA hybridization method. DNA was isolated and purified as described previously (Manachini et al., 1985). DNA-DNA homology was determined by the optical renaturation rates method (Kurtzman et al., 1979) with a model Response spectrophotometer equipped with Advance Kinetics Graphic Version 1.3 thermoprogrammer (Gilford System; Ciba Corning Diagnostic Corp.). For all samples tested the melting temperature $\left(T_{\mathrm{m}}\right)$ was calculated in $5 \times$ SSC, the same salt concentration used for the determination of DNA-DNA similarities. The temperature of hybridization was $25^{\circ} \mathrm{C}$ below the calculated $T_{\mathrm{m}}$. The equation of Seidler \& Mandel (1971) was used to calculate the extent of DNA-DNA reassociation.
Plasmid detection. Detection of plasmid DNA followed the alkaline extraction procedure described by Sambrook et al. (1989).

16S rDNA sequence determination and phylogenetic analysis. Genomic DNA extraction, PCR-mediated amplification of the 16S rDNA and sequencing of the PCR products was carried out as described previously (Rainey et al., 1994). The sequence reactions were electrophoresed using a model 373A automatic DNA sequencer (Applied Biosystems). The 16S rDNA sequences were manually aligned with those of members of thermophilic bacilli and related organisms, deposited in the $16 \mathrm{~S}$ rDNA database of the DSMZ. Evolutionary distances were calculated by the method of Jukes \& Cantor (1969). Phylogenetic dendrograms were reconstructed using the treeing algorithm of DeSoete (1983) and Felsenstein (1993).

Nucleotide sequence accession numbers. The accession numbers of sequences used in the construction of the phylogenetic tree are: Bacillus thermosphaericus DSM 10633 ${ }^{\mathrm{T}}$, X90640; Bacillus thermocloaceae DSM 5250 ${ }^{\mathrm{T}}$, Z26939; Bacillus pasteurii NCIMB 884 ${ }^{\mathrm{T}}$, X60631; Bacillus globisporus DSM 4 ${ }^{\mathrm{T}}$, X68415; Bacillus insolitus DSM $5^{\mathrm{T}}$, X60642; Bacillus subtilis NCDO 1769, X60646; Bacillus smithii DSM 4216 ${ }^{\mathrm{T}}$, Z26935; Bacillus coagulans IAM $12463^{\mathrm{T}}$, Bucillus fastidiosus DSM 91 ${ }^{\mathrm{T}}$, X60615; D16267; Brevibacillus brevis NCIMB 9372 ${ }^{\mathrm{T}}$, X60612; Paenibacillus polymyxa DSM 36 ${ }^{\mathrm{T}}$, X57308; Exiguobacterium aurantiacum NCDO 2321 ${ }^{\mathrm{T}}$, X70316; Planococcus citreus NCIMB $1493^{\mathrm{T}}$, X62172; Kurthia zopfii NCIMB 9878 ${ }^{\mathrm{T}}$, X70321; and Caryophanon latum NCIMB 9533, X70314.

Riboprinting. Ribotyping was performed as described by Allerberger \& Fritschel (1999). Analysis was done with the RiboPrinter Microbial Characterization System (Qualicon) (Bruce, 1996). Each sample lane was normalized to a standard marker set, characterized and identified using similarity measurements to previously run strains and reference patterns. Binary similarity values of riboprint patterns were used to generate a mean linkage clustering dendrogram (Sneath \& Sokal, 1973).

\section{RESULTS}

\section{Phenotypic properties}

The three isolates could not be distinguished from one another nor from Bacillus thermosphaericus DSM $10633^{\mathrm{T}}$ by any of the physiological, morphological or metabolic characteristics tested. Cells were rodshaped, varying in length from 1 to $6 \mu \mathrm{m}$ and approximately $0.5-0.7 \mu \mathrm{m}$ in diameter, motile and occurred singly or in chains. Round spores were located terminally or subterminally within a swollen sporangium (Fig. 1). The Gram reaction was negative. Circular, entire, flat, transparent and swarming colonies were produced. The three isolates grew optimally between 50 and $60{ }^{\circ} \mathrm{C}$. No growth was observed at temperatures above $68^{\circ} \mathrm{C}$, even though at $65^{\circ} \mathrm{C}$ good growth was still observed for isolates $\mathrm{TH}^{\mathrm{A}} \mathrm{A}^{\mathrm{T}}$ and TU1A. No growth was observed below $40{ }^{\circ} \mathrm{C}$, contrary to the type strain that also grew at $35-37^{\circ} \mathrm{C}$. According to the description of Bacillus thermosphaericus species, our isolates and strain DSM $10633^{\mathrm{T}}$ were negative for hydrolysis of starch and gelatin, assimilation of arabinose, ribose, xylose, glucose, maltose, mannose, rhamnose, trehalose, sucrose and citrate, anaerobic 

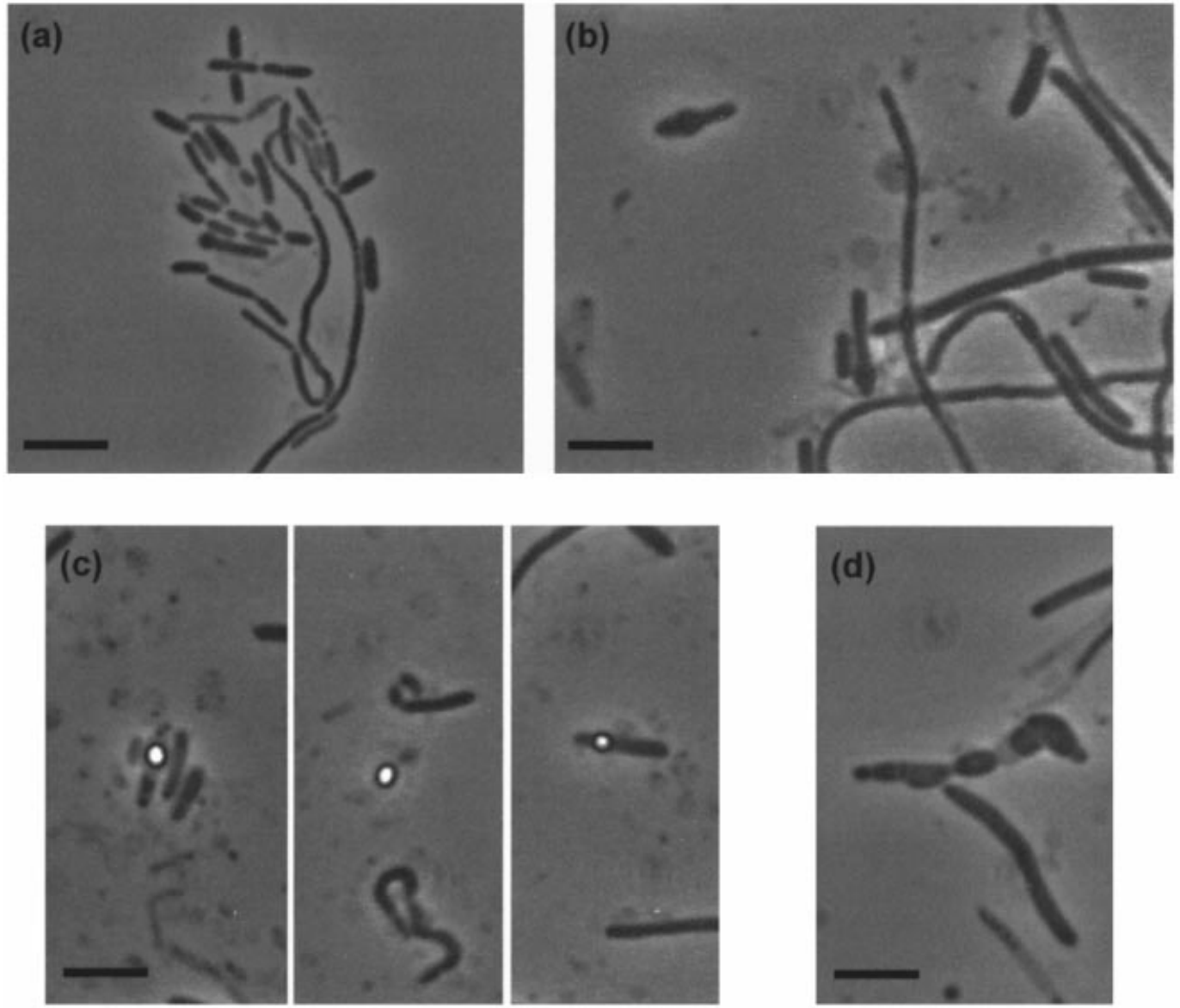

Fig. 1. Phase-contrast micrographs of the type strain of Ureibacillus terrenus grown at $55^{\circ} \mathrm{C}$ on CESP agar. (a) Cells in the vegetative state after $18 \mathrm{~h}$; (b) cells in the foresporal state after $36 \mathrm{~h}$; (c) sporulating cells after $40 \mathrm{~h}$; and (d) giant cells after $66 \mathrm{~h}$. Bar, $5 \mu \mathrm{m}$.

growth, reduction of nitrate and production of indole. They were able to utilize aesculin and urea. In addition to these characteristics, we studied other physiological properties, not yet investigated in Bacillus thermosphaericus species, that would improve its characterization. In particular, all isolates and the type strain were able to grow in presence of $3 \% \mathrm{NaCl}$ and, with the exception of strain TU1A, up to $5 \% \mathrm{NaCl}$. With the exception of strain TU1A, the isolates and the type strain were able to grow in media prepared at $\mathrm{pH} 9 \cdot 0$. Moreover, all tested strains failed to hydrolyse casein and to produce acetylmethylcarbinol. Some of these characteristics distinguished this group of strains from the other thermophilic Bacillus species, such as round spore formation, Gram-negative type cell wall and the inability to grow anaerobically or to use sugars as a source of carbon and energy.

\section{Chemotaxonomic analyses}

The amino acid composition of the peptidoglycan of the three strains matches the data given for Bacillus thermosphaericus DSM 10633 ${ }^{\mathrm{T}}$ (Andersson et al.,
1995). The cross-linkage of the peptidoglycan was of the L-Lys $\leftarrow$ D-Asn type (variation A $4 \alpha$ ) (A11.31); this peptidoglycan type is uncommon within the documented thermophilic bacilli. The phylogenetically nearest neighbour of Bacillus thermosphaericus, Bacillus thermocloaceae, possesses a directly cross-linked peptidoglycan with meso-diaminopimelic acid as the diagnostic amino acid (Demharter \& Hensel, 1989).

Polar lipids, not included in the original description of Bacillus thermosphaericus DSM $10633^{\mathrm{T}}$, were also similar, consisting of phosphatidylglycerol, diphosphatidylglycerol, phospholipids and glycolipids of unknown composition.

Analysis of the fatty acids (Table 1) revealed that all strains of the Bacillus thermosphaericus cluster were characterized by high levels of iso- $\mathrm{C}_{16: 0}$, when grown on solid fatty acid medium (trypticase soy agar; TSA) at $50{ }^{\circ} \mathrm{C}$. Indeed, under these conditions, the strains tested showed predominant amounts of iso- $\mathrm{C}_{16: 0}$ (58-61\%), while iso- $\mathrm{C}_{15: 0}$, iso- $\mathrm{C}_{17: 0}$ and $\mathrm{C}_{16: 0}$ fatty acids occurred in smaller amounts $(13,11$ and $6 \%$ respectively). Other thermophilic bacilli, such as some 
Table 1 Percentage cellular fatty acid composition of the strains tested

The abbreviations for fatty acids are illustrated by the following examples: $\mathrm{C}_{16: 0}$, hexadecanoic acid; i- $\mathrm{C}_{15: 0}, 13-$ methyl tetradecanoic acid; ai- $\mathrm{C}_{17: 0}, 14-$-methyl hexadecanoic acid.

\begin{tabular}{|c|c|c|c|c|c|c|c|c|c|}
\hline Strain & $C_{14: 0}$ & $C_{15: 0}$ & $C_{16: 0}$ & $C_{18: 0}$ & $i-C_{15: 0}$ & $\mathrm{i}-\mathrm{C}_{16: 0}$ & $\mathrm{i}-\mathrm{C}_{17: 0}$ & ai- $C_{15: 0}$ & ai- $C_{17: 0}$ \\
\hline Bacillus thermosphaericus DSM $10633^{\mathrm{T} *}+$ & & $3 \cdot 0$ & $6 \cdot 0$ & & $13 \cdot 0$ & $61 \cdot 0$ & $11 \cdot 0$ & & $1 \cdot 0$ \\
\hline Bacillus thermosphaericus DSM $10633^{\mathrm{T} *}$ & & $2 \cdot 8$ & $5 \cdot 8$ & & $13 \cdot 8$ & $58 \cdot 8$ & $13 \cdot 0$ & & $1 \cdot 0$ \\
\hline $\mathrm{TH}_{9} \mathrm{~A}^{\mathrm{T} *}$ & & $3 \cdot 5$ & $6 \cdot 0$ & & $15 \cdot 8$ & $53 \cdot 6$ & $12 \cdot 2$ & & $1 \cdot 0$ \\
\hline Bacillus thermosphaericus DSM $10633^{\mathrm{T}} \dagger$ & $1 \cdot 1$ & $1 \cdot 0$ & $11 \cdot 6$ & $1 \cdot 0$ & $38 \cdot 6$ & $5 \cdot 1$ & $35 \cdot 0$ & $1 \cdot 2$ & $3 \cdot 0$ \\
\hline $\mathrm{TH} 29 \mathrm{~A} \dagger$ & & & $11 \cdot 4$ & & $40 \cdot 3$ & $7 \cdot 7$ & $29 \cdot 5$ & & $7 \cdot 2$ \\
\hline TU1A $\dagger$ & $1 \cdot 0$ & & $23 \cdot 3$ & $1 \cdot 1$ & $13 \cdot 7$ & $11 \cdot 6$ & $35 \cdot 7$ & $1 \cdot 2$ & $10 \cdot 7$ \\
\hline $\mathrm{TH} 9 \mathrm{~A}^{\mathrm{T}} \dagger$ & & & $12 \cdot 3$ & & $11 \cdot 9$ & $19 \cdot 4$ & $42 \cdot 9$ & & $13 \cdot 5$ \\
\hline
\end{tabular}

* Strains grown in TSA medium.

$\uparrow$ Strains grown in CASO medium.

$\$$ According to Andersson et al. (1995).

Table 2 Major menaquinones of strains tested

\begin{tabular}{|ll|}
\hline Strain & \multicolumn{1}{c|}{ Menaquinones } \\
\hline Bacillus thermosphaericus DSM 10633 & MK-7 \\
TH29A & MK-7, MK-8 $(91: 2)$ \\
TU1A & MK-9, MK-8, MK-10, MK-7 $(51: 37: 6: 3)$ \\
TH9A & MK-9, MK-8, MK-10, MK-7, MK-11 $(58: 22: 14: 1: 1)$ \\
\hline
\end{tabular}

representatives of rRNA group 5 sensu Ash et al. (1991) and the new genus Thermobacillus (Touzel et $a l ., 2000)$ contain iso- $\mathrm{C}_{16: 0}$ as the predominant component, but at lower levels, up to 37 and $48 \%$, respectively. After growth in a different medium (liquid CASO medium, supplemented with yeast extract and glucose) the quantitative composition of fatty acids was different from that previously obtained (Table 1), revealing that the fatty acid composition depends largely not only on the incubation temperature but also on the growth medium used. However, this different growth medium permitted us to distinguish strains DSM $10633^{\mathrm{T}}$ and TH29A from strains TH9A ${ }^{\mathrm{T}}$ and TU1A. In this case the first pair of strains was characterized by the predominance of iso- $\mathrm{C}_{15: 0}$ and iso- $\mathrm{C}_{17: 0}$, accounting for about 40 and $33 \%$, respectively, while the second pair possessed significantly smaller amounts of iso- $\mathrm{C}_{15: 0}(12 \%)$. Some differences in the quantitative composition of the other fatty acids occurred between the two pairs of strains, but were less significant.

Significant chemical differences between the strains tested was detected in the composition of isoprenoid quinones (Table 2). While Bacillus thermosphaericus DSM $10633^{\mathrm{T}}$ and isolate TH29A possessed almost exclusively menaquinone type MK-7 (which accounted for more than $90 \%$ of the total), strains $\mathrm{TH}^{\mathrm{T}} \mathrm{A}^{\mathrm{T}}$ and TU1A showed major amounts of MK-9 ( 58 and $51 \%$ respectively) and MK-8 (22 and 37\%), with MK-7 as a minor component (1 and $6 \%)$.

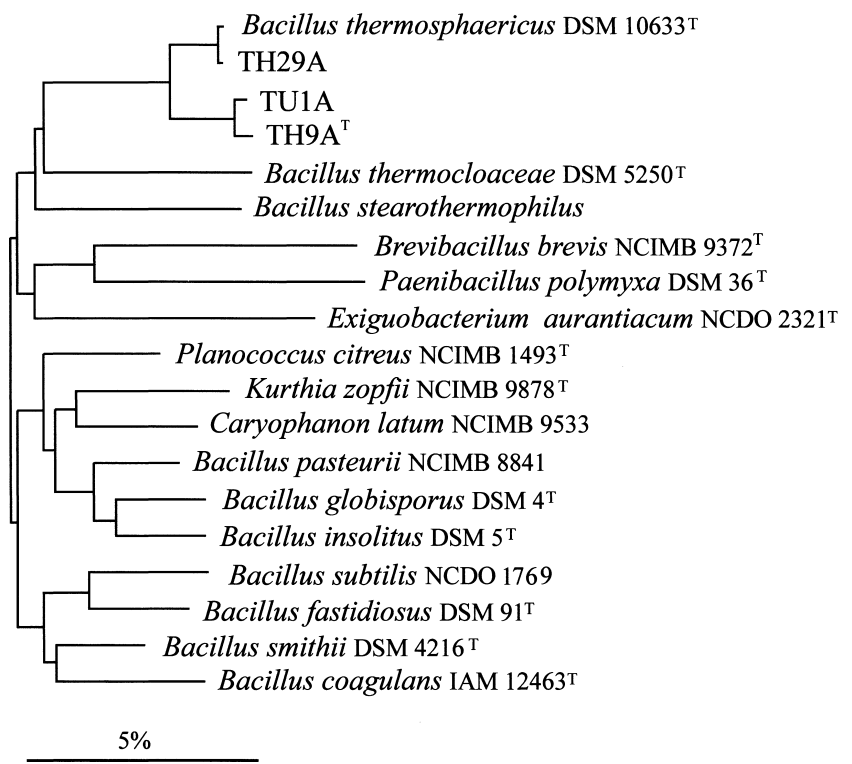

Fig. 2. $16 \mathrm{~S}$ rDNA sequence-based phylogenetic dendrogram constructed from evolutionary distances, showing the phylogenetic position of strains tested, next to members of the genus Bacillus and related taxa. Bar, $5 \%$ sequence similarity.

\section{Phylogenetic analysis}

A continuous stretch of $1305 \mathrm{nt}$ of $16 \mathrm{~S}$ rDNA was determined, ranging from position $18\left(5^{\prime}\right)$ to $1361\left(3^{\prime}\right)$ (Escherichia coli numbering; Brosius et al., 1978). 
Table $3 \mathrm{G}+\mathrm{C}$ content and levels of DNA-DNA reassociation between Bacillus thermosphaericus DSM $10633^{\top}$ and new soil isolates

Percentage reassociation values are means of three determinations; the maximum difference noted between determinations was $7 \%$. Values in parentheses indicate that, by definition, the reassociation value was $100 \%$.

\begin{tabular}{|lcccc|}
\hline Strain & G+C (mol \%) & $\mathbf{1}$ & $\mathbf{2}$ & $\mathbf{3}$ \\
\hline 1. Bacillus thermosphaericus DSM 10633 & $35 \cdot 7$ & $(100)$ & & \\
2. TH9A & & 4 & $(100)$ & \\
3. TU1A & $39 \cdot 6$ & 6 & 98 & $(100)$ \\
4. TH29A & $41 \cdot 5$ & 93 & 25 & 27 \\
\hline
\end{tabular}

Bacillus thermosphaericus DSM 10633
TH29
TH1A

The highest binary $16 \mathrm{~S}$ rDNA similarity values were found with Bacillus thermosphaericus DSM $10633^{\mathrm{T}}$ $(99 \cdot 8-98 \cdot 2 \%$ similarity), while those determined with all other reference strains were significantly lower (91.5-86.2\%; data not shown). The $16 \mathrm{~S}$ rDNA relationships between the strains and the reference organisms of Bacillus and affiliated taxa, depicted in Fig. 2, shows that Bacillus thermosphaericus strains fall within the radiation of the genus Bacillus and represent a distinct lineage within this group, with Bacillus thermocloaceae DSM $5250^{\mathrm{T}}$ being the neighbouring species of Bacillus thermosphaericus DSM $10633^{\mathrm{T}}$ (Andersson et al., 1995). Moreover, it is interesting to note that the strains tested can once again be separated into two groups. One group included Bacillus thermosphaericus DSM $10633^{\mathrm{T}}$ and isolate TH29A with a $16 \mathrm{~S}$ rDNA similarity value of $99 \cdot 8 \%$. The other group included the isolates TH9A ${ }^{\mathrm{T}}$ and TU1A, highly similar $(99.7 \%)$ to each other, but sharing only $98.2 \%$ similarity with the former group.

\section{DNA-DNA homology studies and $\mathrm{G}+\mathrm{C}$ content}

The levels of DNA-DNA homology and the $\mathrm{G}+\mathrm{C}$ contents of the strains are shown in Table 3. It can be seen that the strains tested belonged to two different homology groups, the first comprising strain DSM $10633^{\mathrm{T}}$ and isolate TH29A, and the second the new isolates $\mathrm{TH}^{\mathrm{T}} \mathrm{A}^{\mathrm{T}}$ and TU1A. The DNA G $+\mathrm{C}$ content of Bacillus thermosphaericus DSM $10633^{\mathrm{T}}$, determined by the thermal denaturation method, agrees with that obtained by HPLC (Andersson et al., 1995). Isolate TH29A showed a $\mathrm{G}+\mathrm{C}$ value about $3.5 \mathrm{~mol} \%$ higher, but a difference in thermal stability greater than $2 \%$ is now considered a more realistic standard to delimit bacterial species (Ursing et al., 1995). This less strict definition seems to be particularly sound for the two strains in question, which were closely related either phylogenetically or genetically and phenotypically. The DNA $\mathrm{G}+\mathrm{C}$ content of the other homology group ranged between $39 \cdot 6$ and $41.5 \mathrm{~mol} \%$.

All strains tested were negative for the presence of extrachromosomal elements.

\section{Riboprinting analyses}

The riboprint patterns obtained for the strains studied (Fig. 3) differ from those of all other Bacillus strains (Qualicon Database; data not shown) and also permit the differentiation of the two homology groups. Moreover, while strains $\mathrm{TH}^{\mathrm{T}} \mathrm{A}^{\mathrm{T}}$ and TU1A showed a similar ribopattern that can be considered characteristic of this group, Bacillus thermosphaericus DSM $10633^{\mathrm{T}}$ and isolate TH29A displayed a certain degree of genomic diversity, denoting a genomic uniqueness of these strains that can be used in future identification at the strain level.

\section{DISCUSSION}

In this paper we describe the characterization of a group of thermophilic spore-forming bacteria, including strains TH29A, TH9A ${ }^{\mathrm{T}}$ and TU1A, isolated from uncultivated soil from three different geographical areas. The isolates, based on their phenotypic, chemosystematic and phylogenetic properties, appeared to belong to Bacillus thermosphaericus. This latter species, previously described by Andersson et al. (1995), 
Table 4 Salient features of some genera of aerobic endospore-forming bacteria

Abbreviations: DAP, meso-diaminopimelic acid; S, spherical; O, oval; O-S, oval to spherical spores; i-C iso methyl-branched; ai-C, anteiso methyl-branched; v, character varies according to species; ND, no data available.

\begin{tabular}{|c|c|c|c|c|c|c|}
\hline Character & Ureibacillus & Bacillus* & Virgibacillus $\dagger$ & Brevibacillus & Aneurinibacillus & Alicyclobacillus§ \\
\hline No. of species & 2 & $>60$ & 2 & 10 & 2 & 3 \\
\hline Murein & Lys-D-Asn & $\mathrm{v} \uparrow$ & DAP & DAP & DAP & ND \\
\hline Spore shape & $\mathrm{S}$ & $\mathrm{O}-\mathrm{S}$ & $\mathrm{O}-\mathrm{S}$ & $\mathrm{O}$ & $\mathrm{O}$ & $\mathrm{O}$ \\
\hline Gram reaction & - & $+/ \mathrm{v}$ & + & + & + & + \\
\hline Anaerobic growth & - & $\mathrm{V}$ & + & $\mathrm{V}$ & - & - \\
\hline \multicolumn{7}{|l|}{ Optimum growth: } \\
\hline $\mathrm{pH}$ & $7 \cdot 0-8 \cdot 0$ & $7 \cdot 0-9 \cdot 5$ & $7 \cdot 0$ & $7 \cdot 0$ & $7 \cdot 0$ & $3 \cdot 0$ \\
\hline Temp. $\left({ }^{\circ} \mathrm{C}\right)$ & $50-55$ & $15-55$ & 37 & $30-48$ & 37 & $48-65$ \\
\hline $\begin{array}{l}\text { Major cellular } \\
\text { fatty acids }\end{array}$ & $\mathrm{i}-\mathrm{C}_{16: 0}, \mathrm{i}-\mathrm{C}_{15: 0}, \mathrm{i}-\mathrm{C}_{17: 0}$ & $\mathrm{~V}$ & $\mathrm{i}-\mathrm{C}_{15: 0}, \mathrm{ai}-\mathrm{C}_{15: 0}$ & ai- $C_{15: 0}, \mathrm{i}-\mathrm{C}_{15: 0}$ & $\mathrm{i}-\mathrm{C}_{15: 0}, \mathrm{C}_{16: 0}, \mathrm{i}-\mathrm{C}_{16: 0}$ & $\omega$-Alicyclic acids \\
\hline $\begin{array}{l}\text { Level of intragenus } \\
\text { 16S rRNA gene } \\
\text { sequence similarity } \\
(\%)\end{array}$ & $>98$ & ND & $>99$ & $>93 \cdot 2$ & $98 \cdot 6$ & $>92 \cdot 7$ \\
\hline $\begin{array}{l}\mathrm{G}+\mathrm{C} \text { content } \\
(\mathrm{mol} \%)\end{array}$ & $36-41 \cdot 5$ & $32-69$ & 37 & $46-57$ & $42-43$ & $52-60$ \\
\hline
\end{tabular}

* Data from Claus \& Berkeley (1986).

$\dagger$ Data from Heyndrickx et al. (1998).

$\$$ Data from Shida et al. (1996).

$\S$ Data from Wisotzkey et al. (1992).

$\uparrow$ Predominant type is DAP.

represents a particular thermophilic Bacillus species, for which we believe there are sufficient justifications for the proposal of a new taxon.

Phenotypically, the three new thermophilic isolates and Bacillus thermosphaericus DSM $10633^{\mathrm{T}}$ can be easily distinguished from other taxa on the basis of round spore formation, negative Gram reaction, urease activity and an inability to grow anaerobically or to use sugars as a source of carbon and energy. Moreover, within the thermophilic bacilli, only the Bacillus thermosphaericus group has peptidoglycan type A $4 \alpha$ (L-Lys $\leftarrow$ D-Asn) and a G + C content lower than the other thermophilic bacilli. Moreover, this cluster displays iso- $\mathrm{C}_{16: 0}$ as the main fatty acid, a feature unusual for the genus Bacillus with respect to the high content (about 60\%). These phenotypic and chemotaxonomic differences justify the separation of the strains tested from the other thermophilic bacilli at the genus level.

This conclusion is in agreement with the phylogenetic position of the strains. The $16 \mathrm{~S}$ rDNA sequence data confirm the isolated position of Bacillus thermosphaericus described by Andersson et al. (1995) and show that Bacillus thermocloaceae is the closest phylogenetic neighbour of Bacillus thermosphaericus. However, Bacillus thermocloaceae differs in several phenotypic and chemotaxonomic properties (among which are peptidoglycan type and fatty acid composition)
(Demharter \& Hensel, 1989). Our results also show that the three new thermophilic isolates are phylogenetically related to the reference strain. Sequence comparison reveals intragroup similarity values of more than $98 \cdot 2 \%$. In contrast, the levels of similarity between members of this group and members of previously described genera are consistently less than $91.5 \%$. These intra- and intergroup similarity values indicate that the strains tested are cohesive and distinct from previously described genera.

These accumulated data support the proposal that Bacillus thermosphaericus DSM $10633^{\mathrm{T}}$ and strains TH29A, TH9A ${ }^{\mathrm{T}}$ and TU1A represent the core of a new genus for which the name Ureibacillus gen. nov. is proposed. This new genus is also characterized by the presence of the polar lipids phosphatidylglycerol, diphosphatidylglycerol, phospholipids and glycolipids of unknown composition.

Further characterization of these strains indicates that, within the new genus, two different species can be differentiated. The high level of DNA relatedness $(93 \%)$ between strains DSM $10633^{\mathrm{T}}$ and TH29A underlines that these organisms belong to the same species. This finding is also supported by a high level of $16 \mathrm{~S}$ rDNA sequence similarity $(99 \cdot 8 \%)$. The other two isolates, TH9A ${ }^{\mathrm{T}}$ and TU1A, belong to a different species, sharing only between 4 and $27 \%$ similarity with members of the former species. It is interesting to 
Table 5 Characteristics for distinguishing between Ureibacillus species and the phylogenetically related Bacillus thermocloaceae species

For abbreviations, see Table 4 legend.

\begin{tabular}{|c|c|c|c|}
\hline Characteristic & Ureibacillus thermosphaericus & Ureibacillus terrenus & Bacillus thermocloaceae* \\
\hline Gram reaction & - & - & + \\
\hline Spore shape & $\mathrm{S}$ & $\mathrm{S}$ & $\mathrm{O}$ \\
\hline Murein & Lys-D-Asn & Lys-D-Asn & DAP \\
\hline \multicolumn{4}{|l|}{ Growth at: } \\
\hline $\mathrm{pH} 7 \cdot 0$ & + & + & - \\
\hline $\mathrm{pH} 9 \cdot 0$ & + & $\mathrm{V}$ & + \\
\hline $37^{\circ} \mathrm{C}$ & + & - & + \\
\hline $65^{\circ} \mathrm{C}$ & - & + & + \\
\hline $5 \% \mathrm{NaCl}$ & + & $\mathrm{V}$ & \pm \\
\hline Hydrolysis of urea & + & + & $\mathrm{ND}$ \\
\hline Major cellular fatty acids & $\mathrm{i}-\mathrm{C}_{16: 0}, \mathrm{i}-\mathrm{C}_{15: 0}, \mathrm{i}-\mathrm{C}_{17: 0}$ & $\mathrm{i}-\mathrm{C}_{16: 0}, \mathrm{i}-\mathrm{C}_{15: 0}, \mathrm{i}-\mathrm{C}_{17: 0}$ & $\mathrm{i}-\mathrm{C}_{15: 0}, \mathrm{i}-\mathrm{C}_{17: 0}$ \\
\hline Predominant menaquinone & MK-7 & MK-9, MK-8 & MK-7, MK-8 \\
\hline $\mathrm{G}+\mathrm{C}$ content $(\mathrm{mol} \%)$ & $35 \cdot 7-39 \cdot 2$ & $39 \cdot 6-41 \cdot 5$ & $42-44$ \\
\hline Habitat of isolation & Urban air & Soil & Sewage sludge \\
\hline
\end{tabular}

* Data from Demharter \& Hensel (1989).

note that strains TH9A ${ }^{\mathrm{T}}$ and TU1A (showing a high similarity, $99.7 \%$ ) exhibit a lower level of $16 \mathrm{~S}$ rDNA similarity $(98.2 \%)$ with the other strains, according to the presence of two different homology groups.

These two different homology groups can also be distinguished on the basis of their isoprenoid quinone composition. While strains DSM $10633^{\mathrm{T}}$ and TH29A possess exclusively menaquinones of type MK-7 (accounting for more than $90 \%$ of the total), strains TH9A ${ }^{\mathrm{T}}$ and TU1A possess major amounts of MK-9 and MK-8, with MK-7 as a minor component.

On the basis of DNA-DNA homology values and a distinctive phenotypic trait (menaquinone type), we propose to place two species within the genus Ureibacillus: Ureibacillus thermosphaericus (formerly Bacillus thermosphaericus), including the type strain DSM $10633^{\mathrm{T}}$, isolate TH29A (DSM $12655=$ LMG 19472) and all strains previously described as Bacillus thermosphaericus that share $>70 \%$ DNA-DNA homology with the type strain; and Ureibacillus terrenus sp. nov., including the type strain $\mathrm{TH}^{\mathrm{T}} \mathrm{A}^{\mathrm{T}}\left(=\mathrm{DSM} 12654^{\mathrm{T}}=\right.$ LMG $19470^{\mathrm{T}}$ ) and strain TU1A (DSM $12656=\mathrm{LMG}$ 19471).

The description of the new genus and its species follow and a comparison of some of the salient features of other genera and species of aerobic spore-forming bacteria are shown in Tables 4 and 5 .

\section{Description of Ureibacillus gen. nov.}

Ureibacillus (Ur.e.i.ba.cil'lus. L. n. urea urea; L. dim. n. bacillus from Bacillus, a genus of aerobic endosporeforming bacteria; Ureibacillus a ureolytic aerobic bacillus).
Cells are motile, Gram-negative rods $(0 \cdot 5-$ $0 \cdot 7 \times 1-6 \mu \mathrm{m})$, single or in chains. They bear spherical endospores which lie in terminal or subterminal positions in swollen sporangia. Members of the genus are aerobic, thermophilic bacteria. The cross-linkage of peptidoglycan is of the L-Lys $\leftarrow \mathrm{D}$-Asn type (variation $\mathrm{A} 4 \alpha$ ). The polar lipids are phosphatidylglycerol, diphosphatidylglycerol, phospholipids and glycolipids of unknown composition. The major cellular fatty acid is iso- $\mathrm{C}_{16: 0}$. The $\mathrm{G}+\mathrm{C}$ content ranges from 35.7 to $41.5 \mathrm{~mol} \%$. The levels of $16 \mathrm{~S}$ rRNA gene sequence similarity are more than $98 \%$ for the members of this genus. The type species is Ureibacillus thermosphaericus.

\section{Description of Ureibacillus thermosphaericus (Andersson et al. 1995) comb. nov.}

The description is identical to that given by Andersson et al. (1995) and to the description of the genus given above. Colonies are circular, entire, flat, transparent and swarming. Growth occurs at temperatures ranging from 37 to $60{ }^{\circ} \mathrm{C}$, in the presence of $5 \% \mathrm{NaCl}$ and at $\mathrm{pH} 9 \cdot 0$. Utilizes aesculin and urea. Negative for anaerobic growth, Voges-Proskauer reaction, indole production, nitrate reduction, starch, casein and gelatin hydrolysis, acid production from arabinose, ribose, xylose, glucose, maltose, mannose, rhamnose, trehalose, sucrose and citrate. The major quinone is menaquinone 7. The $\mathrm{G}+\mathrm{C}$ content is $35.7 \mathrm{~mol} \%$ for the type strain and $39 \cdot 2$ for strain TH29A. The type strain is DSM $10633^{\mathrm{T}}$, isolated from urban air and municipal landfill sites. 


\section{Description of Ureibacillus terrenus sp. nov.}

Ureibacillus terrenus (ter.re'nus. L. adj. terrenus from earth, referring to the habitat of the organism).

The main description is identical to the description of the genus and to that given for Ureibacillus thermosphaericus. Can be differentiated from Ureibacillus thermosphaericus by its isoprenoid quinone composition. The main menaquinone types are MK-9 and MK-8, with MK-7 as minor component. Other properties distinguishing Ureibacillus terrenus are growth temperature, ranging from 42 to $65^{\circ} \mathrm{C}$, and the ability to grow at $\mathrm{pH} 9.0$ and in the presence of $5 \% \mathrm{NaCl}$ which is variable within the species. The $\mathrm{G}+\mathrm{C}$ content is $39.6 \mathrm{~mol} \%$ for the type strain and 41.5 for strain TU1A. The habitat is soil. The type strain is DSM $12654^{\mathrm{T}}\left(=\mathrm{LMG} 19470^{\mathrm{T}}\right)$.

\section{REFERENCES}

Allerberger, F. \& Fritschel, S. J. (1999). Use of automated ribotyping of Austrian Listeria monocytogenes isolates to support epidemiological typing. J Micro Methods 35, 237-244.

Andersson, M., Laukkanen, M., Nurmiaho-Lassila, E.-L., Rainey, F. A., Niemela, S. I. \& Salkinoja-Salonen, M. (1995). Bacillus thermosphaericus sp. nov. a new thermophilic ureolytic Bacillus isolated from air. Syst Appl Microbiol 18, 203-220.

Ash, C., Farrow, J. A. E., Wallbanks, S. \& Collins, M. D. (1991). Phylogenetic heterogeneity of the genus Bacillus revealed by comparative analysis of small-subunit-ribosomal RNA sequences. Lett Appl Microbiol 13, 202-206.

Atlas, R. M. (1993). In Handbook of Microbiological Media, p. 967. Edited by L. C. Park. London: CRC Press.

Brosius, J., Palmer, M. L., Kennedy, P. J. \& Noller, H. F. (1978). Complete nucleotide sequence of a $16 \mathrm{~S}$ ribosomal RNA gene from Escherichia coli. Proc Natl Acad Sci U S A 75, 4801-4805.

Bruce, J. (1996). Automated system rapidly identifies and characterizes microorganisms in food. Food Technol January, $77-81$.

Claus, D. \& Berkeley, R. C. W. (1986). Genus Bacillus Cohn 1872. In Bergey's Manual of Systematic Bacteriology, vol. 2, pp. 1105-1139. Edited by P. H. A. Sneath, N. S. Mair, M. E. Sharpe \& J. G. Holt. Baltimore: Williams \& Wilkins.

Collins, M. D. \& Jones, D. (1980). Lipids in the classification and identification of coryneform bacteria containing peptidoglycans based on 2,4-diaminobutyric acid. J Appl Bacteriol 48, 459-470.

Combet-Blanc, Y., Ollivier, B., Streicher, C., Patel, B. K. C., Dwivedi, P. P., Pot, B., Prensier, G. \& Garcia, J.-L. (1995). Bacillus thermoamylovorans sp. nov., a moderately thermophilic and amylolytic bacterium. Int J Syst Bacteriol 45, 9-16.

Demharter, W. \& Hensel, R. (1989). Bacillus thermocloaceae sp. nov., a new thermophilic species from sewage sludge. Syst Appl Microbiol 11, 272-276.

DeSoete, G. (1983). A least square algorithm for fitting additive trees to proximity data. Psychometrika 48, 621-626.

Felsenstein, J. (1993). PHYLIP (Phylogeny Inference Package) version 3.5.1. Seattle: Department of Genetics, University of Washington.

Groth, I., Schumann, P., Weiss, N., Martin, K. \& Rainey, F. A. (1996). Agrococcus jenensis gen. nov., sp. nov., a new genus of actinomycetes with diaminobutyric acid in the cell wall. Int $J$ Syst Bacteriol 46, 234-239.

Groth, I., Schumann, P., Rainey, F. A., Schuetze, B. \& Augsten, K. (1997). Bogoriella caseylitica gen. nov., sp. nov., a new alkaliphilic actinomycete from a Soda Lake in Africa. Int $J$ Syst Bacteriol 47, 788-794.

Heyndrickx, M., Lebbe, L., Kersters, K., De Vos, P., Forsyth, G. \& Logan, N. A. (1998). Virgibacillus: a new genus to accommodate Bacillus pantothenicus (Proom \& Knight 1950). Emended description of Virgibacillus pantothenicus. Int J Syst Bacteriol 48, 99-106.

Jukes, T. H. \& Cantor, C. R. (1969). Evolution of protein molecules. In Mammalian Protein Metabolism, pp. 21-132. Edited by H. N. Munro. New York: Academic Press.

Kurtzman, C. P., Johnson, C. J. \& Smiley, M. J. (1979). Determination of conspecificity of Candida utilis and Hansenula jadinii through DNA reassociation. Mycologia 71, 844-847.

Lanyi, B. (1987). Classical and rapid identification: methods for medically important bacteria. Methods Microbiol 19, 1-67.

MacKenzie, S. L. (1987). Gas chromatographic analysis of amino acids as the $N$-heptafluorobutyryl isobutyl esters. J Assoc Off Anal Chem 70, 151-160.

Manachini, P. L., Fortina, M. G., Parini, C. \& Craveri, R. (1985). Bacillus thermoruber sp. nov., nom. rev., a red-pigmented thermophilic bacterium. Int J Syst Bacteriol 35, 493-496.

Marmur, J. \& Doty, P. (1962). Determination of the base composition of deoxyribonucleic acid from its thermal denaturation temperature. J Mol Biol 5, 109-118.

Meier-Stauffer, K., Busse, H.-J., Rainey, F. A., Burghardt, J., Scheberl, A., Hollaus, F., Kuen, B., Makristathis, A., Sleytr, U. B. \& Messner, P. (1996). Description of Bacillus thermoaerophilus sp. nov., to include sugar beet isolates and Bacillus brevis ATCC 12990. Int J Syst Bacteriol 46, 532-541.

Minnikin, D. E., Collins, M. D. \& Goodfellow, M. (1979). Fatty acid and polar lipid composition in the classification of Cellulomonas, Oerskovia and related taxa. J Appl Bacteriol 47, 87-95.

Mora, D., Fortina, M. G., Nicastro, G., Parini, C. \& Manachini, P. L. (1998). Genotypic characterization of thermophilic bacilli: a study on new isolates and several reference strains. Res Microbiol 149, 711-722.

Owen, R. J. \& Hill, L. R. (1979). The estimation of base composition, base pairing and genome sizes of bacterial deoxyribonucleic acid. In Identification Methods for Microbiologists, pp. 277-296. Edited by F. A. Skinner \& D. W. Lovelock. London: Academic Press.

Pettersson, B., Lembke, F., Hammer, P., Stackebrandt, E. \& Priest, F. G. (1996). Bacillus sporothermodurans, a new species producing highly heat-resistant endospores. Int J Syst Bacteriol 46, 759-764.

Rainey, F. A., Fritze, D. \& Stackebrandt, E. (1994). The phylogenetic diversity of thermophilic members of the genus Bacillus as revealed by $16 \mathrm{~S}$ rDNA analysis. FEMS Microbiol Lett 115, 205-212.

Salle, A. Y. (1961). Laboratory Manual on Fundamental Principles of Bacteriology. New York: McGraw-Hill.

Sambrook, J., Fritsch, E. F. \& Maniatis, T. (1989). Molecular Cloning : a Laboratory Manual, 2nd edn. Cold Spring Harbor, NY : Cold Spring Harbor Laboratory.

Schleifer, K. H. (1985). Analysis of the chemical composition and primary structure of murein. Methods Microbiol 18, 123-156. 
Schleifer, K. H. \& Kandler, O. (1972). Peptidoglycan types of bacterial cell walls and their taxonomic implications. Bacteriol Rev 36, 407-477.

Schumann, P., Prauser, H., Rainey, F. A., Stackebrandt, E. \& Hirsch, P. (1997). Friedmaniella antarctica gen. nov., sp. nov., an L-diaminopimelic acid-containing actinomycete from Antarctic sandstone. Int J Syst Bacteriol 47, 278-283.

Seidler, R. J. \& Mandel, M. (1971). Quantitative aspects of deoxyribonucleic acid renaturation: base composition, state of chromosome replication and polynucleotide homologies. $J$ Bacteriol 106, 608-614.

Shida, O., Takagi, H., Kadowari, K. \& Komagata, K. (1996). Proposal for two new genera, Brevibacillus gen. nov. and Aneurinibacillus gen. nov. Int J Syst Bacteriol 46, 939-946.

Smith, N. R., Gordon, R. E. \& Clark, F. E. (1952). Aerobic Sporeforming Bacteria. Agriculture Monograph No. 16. Washington, DC: US Department of Agriculture.

Sneath, P. H. A. \& Sokal, R. R. (1973). Numerical Taxonomy: the Principles and Practice of Numerical Classification. San Francisco: Freeman.
Touzel, J. P., O'Donohue, M., Debeire, P., Samain, E. \& Breton, C. (2000). Thermobacillus xylanilyticus gen. nov., sp. nov., a new aerobic thermophilic xylan-degrading bacterium isolated from farm soil. Int J Syst Bacteriol 50, 315-320.

Ursing, J. B., Rossellò-Mora, R. A., Garcìa-Valdés, E. \& Lalucat, J. (1995). Taxonomic note: a pragmatic approach to the nomenclature of phenotypically similar genomic groups. Int J Syst Bacteriol 45, 604.

Wainø, M., Tindall, B. J., Schumann, P. \& Ingvorsen, K. (1999). Gracilibacillus gen. nov., with description of Gracilibacillus halotolerans gen. nov., sp. nov.; transfer of Bacillus dipsosauri to Gracilibacillus dipsosauri comb. nov., and Bacillus salexigens to the genus Salibacillus gen. nov., as Salibacillus salexigens. comb. nov. Int J Syst Bacteriol 49, 821-831.

Wisotzkey, J. D., Jurtshuk, P. J. R., Fox, G. E., Deinhard, G. \& Poralla, K. (1992). Comparative sequence analyses on the $16 \mathrm{~S}$ rRNA (rDNA) of Bacillus acidocaldarius, Bacillus acidoterrestris, and Bacillus cycloheptanicus and proposal for creation of a new genus, Alicyclobacillus gen. nov. Int J Syst Bacteriol 42, 263-269. 